\title{
BIRDS
}

\section{POPULATION SIZE AND PRODUCTIVITY OF PIPING PLOVERS AT LAKE DIEFENBAKER IN RELATION TO WATER LEVEL.}

MARGARET A. SKEEL* and DAVID C. DUNCAN**, Saskatchewan Wetland Conservation Corporation, 202 - 2050 Cornwall Street, Regina, SK S4P 2K5.

*current address: Nature Saskatchewan, Room 206, 1860 Lorne St., Regina, SK S4P 2 L4.

${ }^{\star *}$ current address: Canadian Wildlife Service, Room 200, 4999-98 Avenue, Edmonton, $A B$ T6B $2 \times 3$

In the breeding season Lake Diefenbaker is home to a significant, although 'varying, portion of the world Piping Plover population. This presents eproductive challenges to the Piping lover, an endangered species, because water level in this huge reservoir ften rises from 2-6 $\mathrm{m}$ between early May and late July, the plover's breeding eriod. There is growing concern among onservationists that reproductive osses due to flooding of nests and disppearance of brood-rearing habitat inder flooded beaches may be hinderig recovery efforts of this species. A imulation model developed to assess he effects of flooding on Piping Plover eproductive success at Lake Diefenbaker over the last 30 years sugests that flooding of nests and chickearing habitat has had a detrimental ffect on productivity ${ }^{3}$. By attracting large umbers of breeding plovers to its eaches in some years, with subseuent high reproductive losses due to sing water level, Lake Diefenbaker may e a "sink" rather than a "source" for the lover population.
The 1991 and 1996 international Piping Plover censuses suggested that $64 \%$ and $60 \%$, respectively, of the Canadian population of breeding Piping Plovers occurred in Saskatchewan. ${ }^{18} 19$ This represents $23 \%$ and $21 \%$, respectively, of the total North American population. Within Saskatchewan, Lake Diefenbaker was identified as a particularly important breeding area for Piping Plovers in some years. In 1991, 24\% of the Saskatchewan population bred there, representing about $5 \%$ of the world population. However, only $6 \%$ of the Saskatchewan population bred there in 1996. Piping Plovers move from year to year in response to changing water regimes. We summarize data from various studies from 1984 to 1996 on population size, distribution, productivity, and other reproductive variables of Piping Plovers at Lake Diefenbaker. The data is standardized and presented in a uniform format in order to make comparisons among years. This summary strongly suggests that Piping Plovers are often not faring well in their reproductive efforts due to changing water level at Lake Diefenbaker. Further stud- 


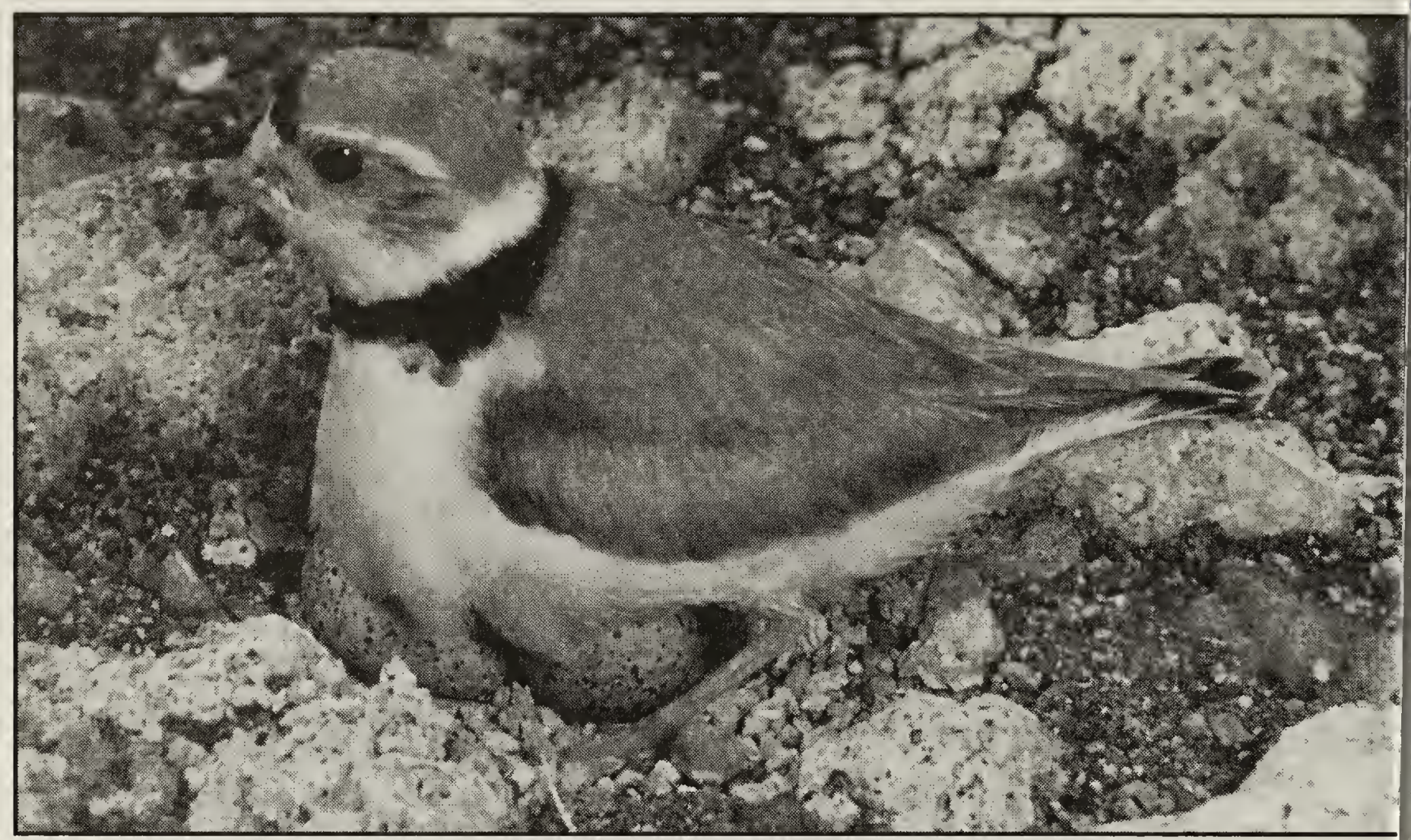

Piping Plover

Ian W. Sadle

ies will clarify potential management actions that may enhance the Piping Plovers' productivity in some years at this site.

Population Studies Lake Diefenbaker was confirmed as an important basin to breeding Piping Plovers in 1984 when the first census was conducted there ${ }^{10}$. Survey data from 1984 to 1996 indicates that numbers of plovers using the reservoir is highly variable from year to year (Table 1).

A complete census occurred in only 4 of the 10 years for which population counts were conducted between the end of May and the first half of June: in 1988 , 1991, 1992 and 1996. Most of the shoreline with suitable habitat was censused in the other years except for 1993, when only 5 small, but important, study sites were monitored ${ }^{2}$. In order to have the population survey information comparable among years, a population estimate was calculated for the years of incomplete censuses ${ }^{17}$. The estimates were determined as follows (except for 1993): for portions of the shoreline that were not censused in a given year, the aver- age number of birds counted in those portions was calculated from year: when the overall population count wa similar to the year in question. This esti mate was added to the actual count fron the censused portions of the lake for the year. For 1993, the estimate was detel mined using the 1992 sites as an inde of the total population: the 3 sites hac on average, $40.7 \%$ of the total popule tion in 3 years of complete counts (1991992, and 1996) ${ }^{1}$. The 1993 count at th 3 sites was assumed to be $40.7 \%$ of th total population. Population distributio and shoreline areas censused in eac year were also mapped ${ }^{17}$.

One question about population flur tuations that arises is: why are numbe so variable among years? One hypotl esis speculates that years of high popi lation numbers may occur in years whe water levels are low, and thus expose beaches are wider, at the time plove are arriving. To examine this idea, th population counts for years of comple censuses and the estimated populatic for years of incomplete censuses we compared to the water level in the re ervoir on May 12 of that year (Figure. 


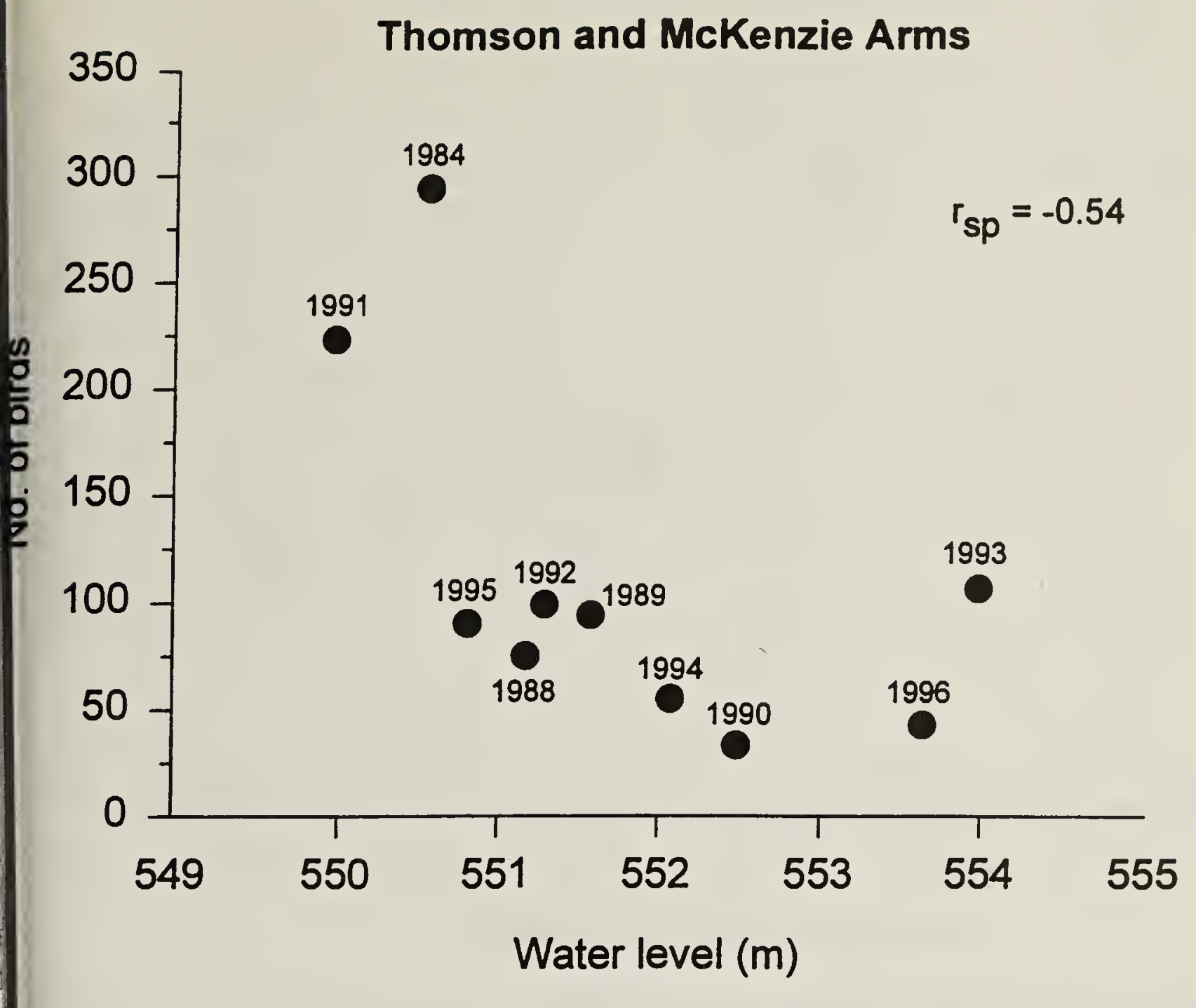

Riverhurst Ferry to the Dams

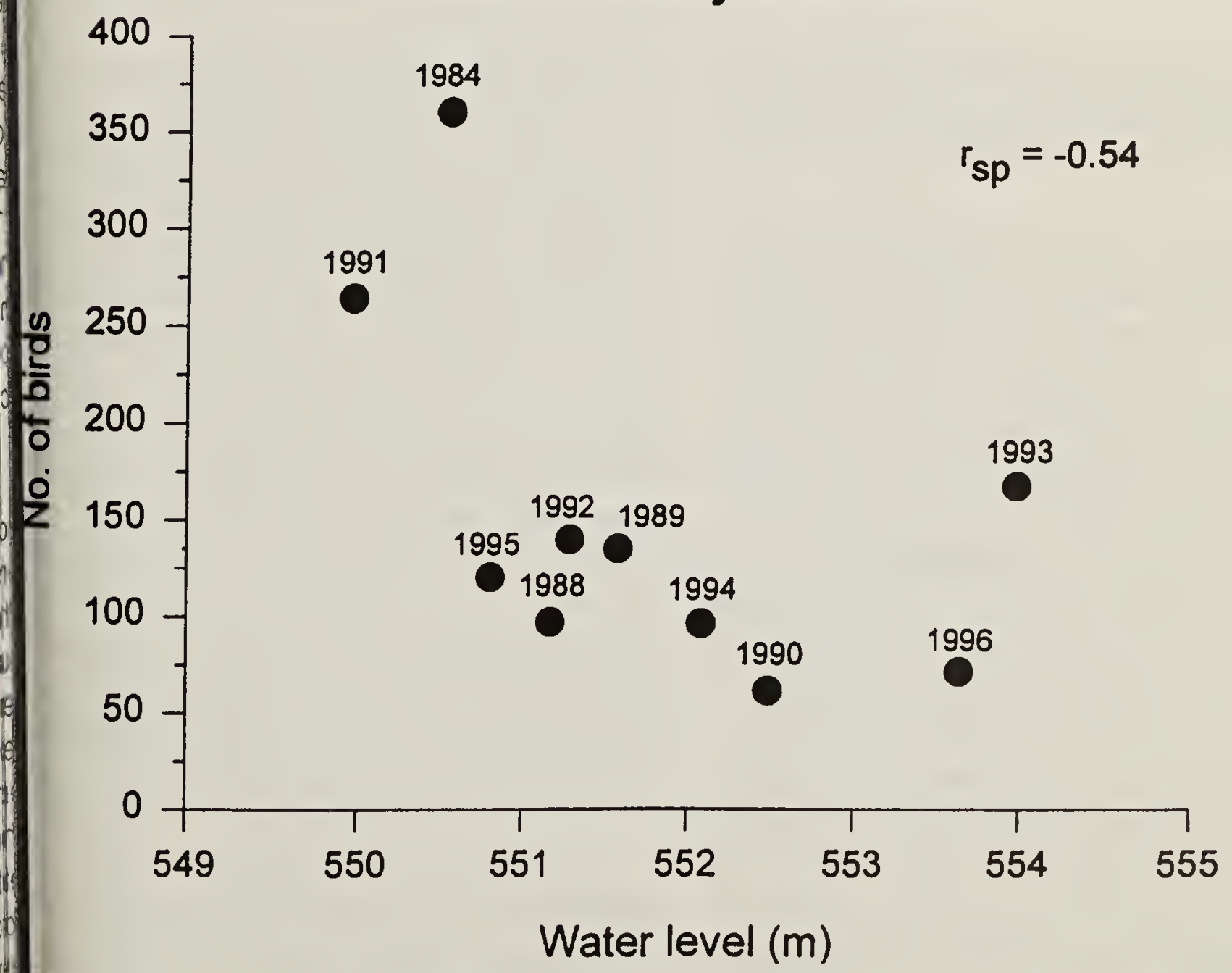

Figure 1. Number of Piping Plovers at Lake Diefenbaker versus May 12 water evel 


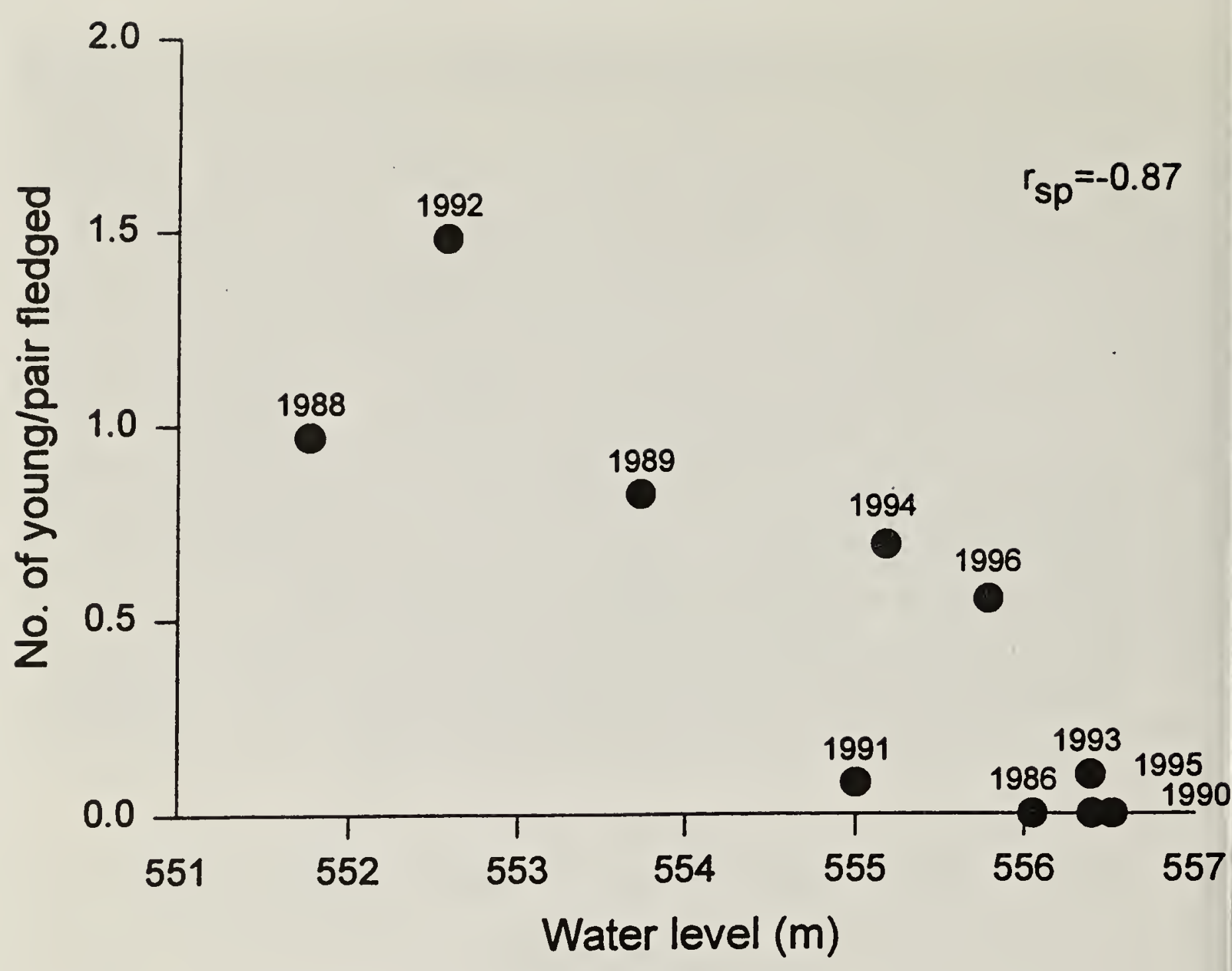

Figure 2. Fledging rate of Piping Plovers at Lake Diefenbaker versus July 1 wate levels.

May 12 was used because it is the mean initiation date for Piping Plover nests at Lake Diefenbaker (Table 2).

A relationship between May 12 water level and the number of plovers inhabiting Lake Diefenbaker is apparent (Figure 1). At water levels below $550.8 \mathrm{~m}$ (above sea level), the number of plovers increases to high levels. In 1993, the estimated population appears slightly anomalous being somewhat higher than expected with a May 12 water level of $554.0 \mathrm{~m}$. The population estimate for 1993 will be less reliable than that of other years for 2 reasons. First, this was the year when the least amount of shoreline was actually censused and thus the greatest extrapolation was required. Second, the estimate is based on more thorough and numerous counts than the typical count and therefore may be higher.
An alternative hypothesis to the ques tion of why numbers are so variable among years is that years of high popu lation numbers may follow years of high fledging success because birds may return to areas where they successfuilly bred at higher rates than unsuccessfu breeders, and young may also home This hypothesis predicts that years 0 high productivity would be followed b: years of higher populations. A cursor comparison between the number 0 plovers in one year, and the fledgin! success the previous year strongly sug gests that no relationship exists betweel these two parameters. Hence the pro ductivity hypothesis is rejected.

The apparent relationship betwee population level and May water level $\mathrm{i}$ the reservoir suggests some possibl water management options. Becaus rapidly rising water level in June and th 


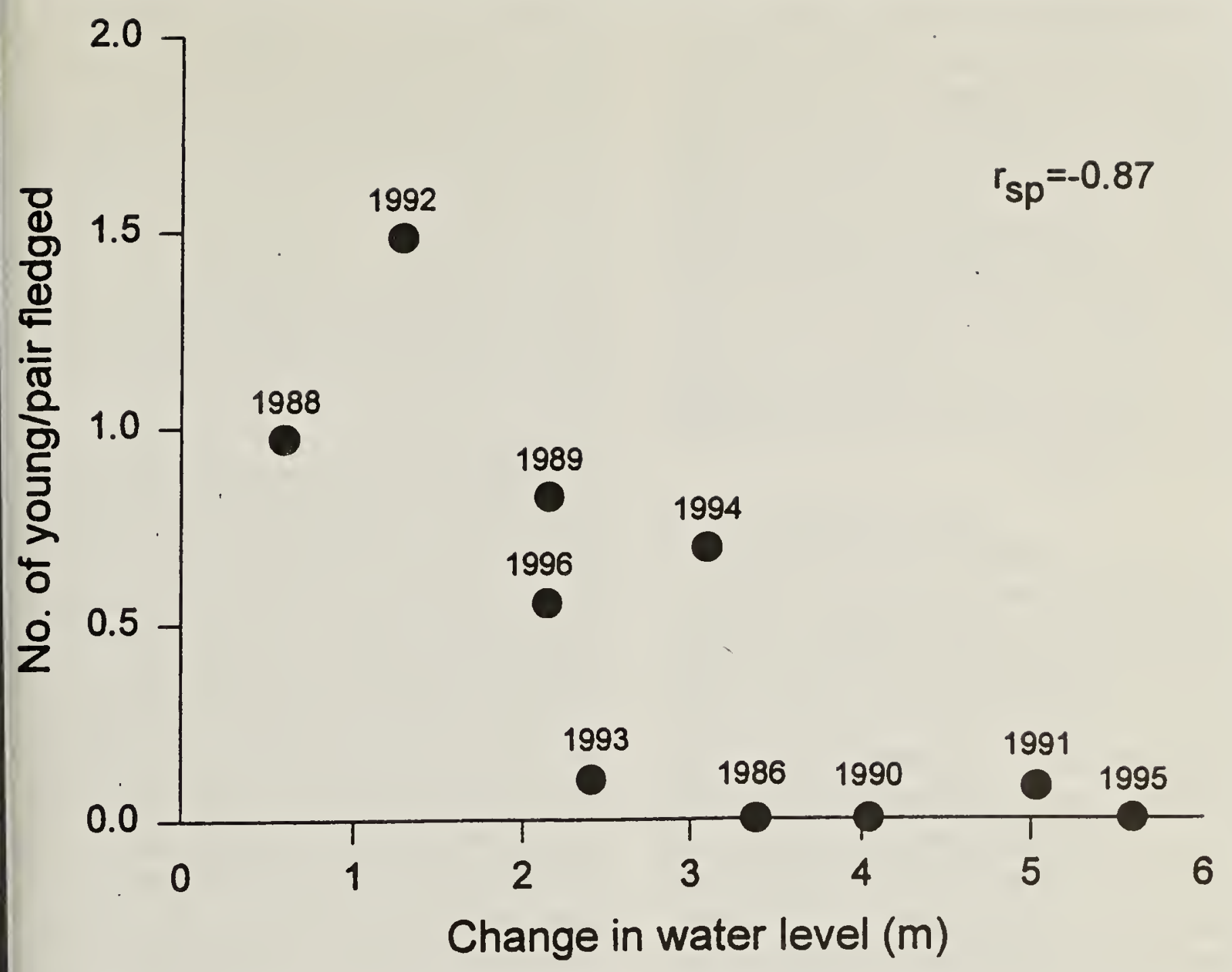

Figure 3. Fledging rate of Piping Plovers at Lake Diefenbaker versus change in water level from May 12 to July 1.

first half of July has been identified as the major threat to Piping Plover productivity at Lake Diefenbaker, it may be desirable to keep the population of plovers at Lake Diefenbaker low in years when rapid increases in water levels are expected over the summer $2,7,8,9,11,13,14,20$. Alternatively, it may be desirable to keep plover populations low in all years, although perhaps with the exception of extended periods of drought when Lake Diefenbaker's importance to plovers may increase as habitat at smaller basins diminishes ${ }^{16}$. The data from 1984 to 1996 strongly suggests that population levels of Piping Plovers can be minimized by keeping water levels $>550.8$ $m$ on May 12 (Figure 1).

Productivity Studies The hatching and nest success of Piping Plovers was determined from a sample of the popuation for 5 years from 1991 to 1996 (Ta- ble 1). A measure of fledging success is determined from samples for 10 years from 1986 to 1996 (Table 1).

Hatching success (the number of chicks hatching per pair) varied from 0.6 2.4 young/pair. In all years the nests examined were distributed around the lake, with the exception of 1993 when most nests were located near the Qu'Appelle Dam². Hatching success may be slightly inflated for 1993 as 1992 data (subset, Table 1) indicates slightly higher hatching success near the Qu'Appelle Dam than overall at the lake.

Nest success (per cent of nests hatching $>1$ chicks) varied from $7-60 \%$ and was often low. Calculated nest success, or Green's estimator of calculated nest success, are used (rather than observed apparent nest success) as these more accurately reflect actual nest success 
by determining a success rate from the time a nest is located until it hatched or failed ${ }^{12,4}$. The proportion of nests lost to flooding was high (40-60\% of all nests) in 4 of the 5 years: 9 of 22 nests in 1991, 1 of 30 nests in 1992, 23 of 39 nests in 1993, 13 of 32 nests in 1995, and 8 of 20 nests in $1996^{14,20,2,13,11}$.

Fledging success (the number of chicks fledging per pair) was calculated in 1 of 2 ways:

(1) In some years a brood census was conducted in early July. An estimated fledging success was determined for each of these years in the following manner: the number of young on the brood census was compared to the number of pairs that were counted over the same census area on the late May to early June pair census. Data and maps from reports were used to determine number of pairs and census areas. Territorial individuals are included as pairs; in 1991 Harris and Lamont found all territorial birds $(n=13)$ to be associated with nests ${ }^{9}$. Fledging success calculated from a July brood census represents an index of fledging success, rather than actual fledging success. This index may vary from actual fledging success because it assumes all young counted on a brood census survive to fledging (averaging 1 week later), and that a one-time brood census is as accurate as regularly monitoring a brood.

(2) In the other years, fledging rate was determined by the more accurate method of monitoring a specific sample of nests through until fledging. This occurred from 1991-1996 excluding 1994. In some instances the index to fledging success may reflect a truer fledging success as it includes a larger and more broadly distributed sample. In 1991, no young fledged from the sample of 22 nests, whereas an estimated fledging success index of 0.1 young/pair was determined from an early July brood census of the Arms (91 pairs), which yielded 7 young ${ }^{14,9}$. In 1992, the fledging rate was determined from a sample of nests in which most were located at one study site 1 . The estimated fledging success index for this year determined from an early July brood census, may again be more representative of the lake as a whole ${ }^{20}$.

Fledging success, like the population count of plovers at Lake Diefenbaker, is highly variable among years. When fledging success is compared to July 1 water level in the reservoir, a strong relationship is apparent (Figure 2). By July 1 most nests have hatched (mean hatch date is June 14; Table 2), and sufficient chick-rearing habitat is critical to fledging success (mean fledge date is July 9; Table 2). When July 1 water level is above $556.0 \mathrm{~m}$, fledging success is consistently near zero. In 2 of the 3 years when the July 1 water level was 555.0$556.0 \mathrm{~m}$, fledging success was noticeably higher than the other year (1991) when fledging success was near zero. In the 2 years of higher fledging success (1994 and 1996), birds may have been nesting higher up on beaches than in 1991 because the May 12 water level in 1991 was very low compared to 1994 and 1996. This may have provided considerably more opportunity for birds to nest lower on the beaches in 1991, and thus resulted in a higher risk of loss to flooding as water level rose.

When fledging success is comparec to the increase in water level betweer May 12 and July 1 another strong rela. tionship emerges (Figure 3). Highe fledging rates occurred at lower changes in water level. When water level in creases were $>3.1 \mathrm{~m}$, complete or nearls complete reproductive failure occurred It is apparent that both May 12 wate level and increase in water level be tween May 12 and July 1 are importan 
to fledging success. The 2 years with the highest fledging success (1988 and 1992) had the lowest May 12 water level (\#550.8 $\mathrm{m}$ ) and the lowest change in water level between May 12 and July 1 (\#1.3 m).

The strong relationship between fledging success and both July 1 water level and increase in water level between May 12 and July 1 provides another opportunity for water management. In the 5 years when the July 1 water level was $<556.0 \mathrm{~m}$ and the water level rise between May 12 and July 1 was <3.1 m (1988, 1989, 1992, 1994, and 1996), complete or nearly complete reproductive failure was avoided and fledging success averaged 0.90 young/ pair $(n=5$ years; range $=0.6-1.5$ young/ pair). In the 5 years when water regimes did not follow this pattern, fledging success was near zero. The data suggests that water regimes conforming to the former parameters would greatly improve productivity of plovers at Lake Diefenbaker.

The suggested reproductive success for an annual population increase of $1 \%$ for this endangered species is 1.16 young per pair ${ }^{15}$. Although the fledging success was above the 1.16 young/pair rate in only 1 year (1992), the average fledging success of 0.90 young/pair for the 5 years approaches this value. A water management regime that averages $\$ 1.16$ young per pair over all years would enhance recovery of this species overall.

Fledging success might also be increased if other management action were taken near the Qu'Appelle Dam where high concentrations of nesting plovers consistently occur. In 19911996 , from $10-35 \%$ of the reservoir's population were counted along the shore west of the Dam in the vicinity of Summit Creek. In 1992, when overall fledging success was estimated at 1.5 young/pair, the success at a study site north of Summit Creek was very high at 2.5 young/pair (48 chicks from 19 nests) ${ }^{20,1}$. With its high concentration of plovers and high fledging rate in years when nests are not flooded, maintenance and possibly enhancement of this beach area, and/or management of the plovers which nest there, may be considered.

\section{Acknowledgements}

We are grateful to the many people involved in the studies of Piping Plovers at Lake Diefenbaker over the past years. The completeness of this summary is due to their dedication and effort in collecting data. We thank Don McKinnon for calculating the Green's estimator for nest success, Steve Davis for help with the graphs, and Dave Richards for providing Lake Diefenbaker water levels.

1.ESPIE, R.H.M., R.M. BRIGHAM and P.C. JAMES. 1992. Breeding ecology of the Piping Plover at Lake Diefenbaker, Saskatchewan. Canadian Wildlife Service, Edmonton. Unpub. 31 pp.

2.ESPIE, R.H.M., P.C. JAMES AND R.M. BRIGHAM. 1994. The effect of water level fluctuations on Piping Plover (Charadrius melodus) breeding success at Lake Diefenbaker, Saskatchewan. Canadian Wildlife Service, Edmonton. Unpub. 31 pp plus appendix.

3._. In press. The effects of flooding on Piping Plover Charadrius melodus reproductive success at Lake Diefenbaker, Saskatchewan, Canada. Biological Conservation.

4.GREEN, R.E. 1989. Transformation of crude proportions of nests that are successful for comparison with Mayfield estimates of nest success. Ibis 131: 305-306. 
5.HAIG, S.M. 1991. Piping Plover. Pages 1-16 in A. Poole, P. Stettenheim and F. Gill,(eds.), Birds of North America. American Ornithologists Union, Philadelphia, Pa.

6.HARRIS, W.C. 1988. Piping Plover survey - 1988: South Saskatchewan River - Lake Diefenbaker segment (Riverhurst Ferry to the Dams). Sask. Natural History Society, Regina. Unpub. $10 \mathrm{pp}$. plus map.

7.HARRIS, W.C., S.M. LAMONT and A. SEQUIN. 1989. Saskatchewan Piping Plover surveys - 1989: Big Quill Lake, Lake Diefenbaker, and Redberry Lake. Sask. Natural History Society, Regina. Unpub. 18 pp.

8.HARRIS, W.C. and S.M. LAMONT. 1990. Saskatchewan Piping Plover population assessment - 1990: Big Quill Lake, Chaplin Lake, Lake Diefenbaker, Redberry Lake and the South Saskatchewan River (Gardiner Dam to Saskatoon). Sask. Environmental Society, Saskatoon. Unpub. 15 pp. plus appendix.

9.HARRIS, W.C. and S.M. LAMONT. 1991. Saskatchewan Piping Plover population assessment - 1991: Big Quill Lake, Chaplin Lake, Lake Diefenbaker, Redberry Lake and the South Saskatchewan River (Gardiner Dam to Saskatoon). Sask. Environmental Society, Saskatoon. Unpub. 32 pp. plus maps.

10.HARRIS, W.C., G. WAPPLE, R. WAPPLE, K. DESMET and S.M. LAMONT. 1985. Saskatchewan Piping Plovers - 1984. Sask. Natural History Society and Sask. Parks \& Renewable Resources, Regina. Unpub. 106 pp. plus appendix.

11.HJERTAAS, P. 1996. 1996 Piping Plover follow-up at Lake Diefenbaker. Sask. Wetland Conservation Corp., Regina. Unpub. 8 pp.
12.MAYFIELD, H.F. 1975. Suggestions for calculating nest success. Wilson Bulletin 87: 456-466.

13.MCADAM, S.M. 1995. Lake Diefenbaker Piping Plover survey 1995. Sask. Wetland Conservation Corp., Regina. Unpub. $21 \mathrm{pp}$.

14.ROBINSON, L. and D. HJERTAAS. 1991. The effect of water level management on the Piping Plover at Lake Diefenbaker. Sask. Parks \& Renewable Resources. Unpub. 35 pp.

15.RYAN, M.R., B.G. ROOT and P.M. MAYER. 1993. Status of Piping Plovers in the Great Plains of North America: A demographic simulation model. Conservation Biology 7: 581-585.

16.SKEEL, M.A. 1994. The 1991 Piping Plover census in Saskatchewan. Pages 35-42 in Fleming, S.F. (ed.), The 1991 International Piping Plover Census in Canada. Canadian Wildlife Service Occasional Paper No. 82, Ottawa.

17.SKEEL, M.A. 1997. Population size and productivity of Piping Plovers at Lake Diefenbaker in relation to water levels - 1984 to 1996. Sask. Wetland Conservation Corporation, Regina. Unpub. 20 pp. plus appendices.

18.SKEEL, M.A., D.C. DUNCAN and E.R. WILTSE. 1996. Saskatchewan results of the 1996 international Piping Plover census. Blue Jay55(3): 157-168.

19.SKEEL, M.A. and D. HJERTAAS. 1993. Saskatchewan results of the 1991 international Piping Plover census. Blue Jay 51(1): 36-46.

20.WAIT, B. 1992. Piping Plover Survey of Lake Diefenbaker - 1992. Environment \& Resource Management, Regina. Unpub. 7 pp. 
Table 1. Population size and productivity of piping plovers at Lake Diefenbaker, Saskatchewan, from ferry to the Gardiner and Qu'Appelle Dams. Productivity is determined from a sample of the population

\begin{tabular}{|c|c|c|c|c|c|c|c|c|c|}
\hline Year & $\begin{array}{l}\text { No. }{ }^{a} \\
\text { of } \\
\text { birds }\end{array}$ & \begin{tabular}{|l} 
No. \\
of \\
pairs
\end{tabular} & $\begin{array}{l}\text { No. of } \\
\text { nests in } \\
\text { sample }\end{array}$ & $\begin{array}{l}\text { No. of } \\
\text { young } \\
\text { hatched }\end{array}$ & $\begin{array}{l}\text { Hatching } \\
\text { success } \\
\text { (yg/pr) }\end{array}$ & $\begin{array}{l}\text { Nest } \\
\text { success } \\
(\$)^{b}\end{array}$ & $\begin{array}{l}\text { No.: of } \\
\text { young } \\
\text { fledged } \\
\end{array}$ & $\begin{array}{l}\text { Fledging } \\
\text { success } \\
\text { (yg/pr) }\end{array}$ & $\begin{array}{l}\text { Pair } \\
\text { success } \\
(i,)^{\prime}\end{array}$ \\
\hline $1984^{1 r}$ & $\begin{array}{l}360 \quad E \\
{[217]}\end{array}$ & {$[98]$} & -- & -- & -- & -- & -- & -- & -- \\
\hline $1986^{d}$ & low & low & -- & -- & - & -- & 0 & 0 & 0 \\
\hline 1988 & $97^{6}$ & $46^{5}$ & $35^{\S}$ & -- & -- & -- & $34^{7} \mathrm{E}$ & $1.0 \mathrm{E}$ & -- \\
\hline $1989^{?}$ & $\begin{array}{l}135 \mathrm{E} \\
{[94]} \\
\end{array}$ & {$[35]$} & 35 & -- & -- & -- & $27 E$ & $0.8 \mathrm{E}$ & $37.1 \mathrm{E}$ \\
\hline $1990^{8}$ & $\begin{array}{l}61 \mathrm{E} \\
{[33]}\end{array}$ & {$[11]$} & 7 & -- & -- & -- & 0 & 0 & 0 \\
\hline 1991 & $264^{19}$ & $116^{-9}$ & $22^{14}$ & $13^{24}$ & $0.6: 4$ & $20.5^{14} \mathrm{G}$ & $0^{14}$ & $0^{14}$ & $0^{1 i}$ \\
\hline \multicolumn{3}{|c|}{1991 Arms only } & $91^{8}$ & -- & -- & -- & $7^{9} \mathrm{E}$ & $0.1^{9} \mathrm{E}$ & $6.6^{8} \mathrm{E}$ \\
\hline $1992^{20}$ & 140 & 78 & $\begin{array}{l}40 \\
62 \mathrm{E} \\
\end{array}$ & $\begin{array}{l}96 \\
-- \\
\end{array}$ & $\begin{array}{l}2.4 \\
-- \\
\end{array}$ & $\begin{array}{ll}47.7 \quad G \\
--\end{array}$ & $92 \mathrm{E}$ & -- & $61.3 \mathrm{E}$ \\
\hline \multicolumn{3}{|c|}{ subset of above ${ }^{1}$} & 30 & 83 & 2.8 & $60.1 \mathrm{G}$ & 55 & 2.0 & 71.4 \\
\hline $1993^{2}$ & $\begin{array}{l}167 \mathrm{E} \\
{[78]}\end{array}$ & [39] & 39 & 33 & 0.8 & $8.6 \quad \mathrm{G}$ & 4 & 0.1 & 5.1 \\
\hline $1994^{\circ}$ & $\begin{array}{c}96 \mathrm{E} \\
{[83]} \\
\end{array}$ & [39] & $39 \mathrm{E}$ & -- & -- & -- & $27 \mathrm{E}$ & $0.7 \mathrm{E}$ & $38.5 \mathrm{E}$ \\
\hline $1995^{13}$ & $\begin{array}{l}120 E \\
{[102]} \\
\end{array}$ & [45] & 29 & 21 & 0.7 & $6.8 \mathrm{C}$ & 0 & 0 & 0 \\
\hline 1996 & $71^{103}$ & $28^{16}$ & $20 \cdot 1$ & $35^{11}$ & $1.8^{11}$ & $33.0^{\circ} \mathrm{C}$ & $11^{11}$ & $0.6^{11}$ & $25.0:=$ \\
\hline
\end{tabular}

${ }^{\mathrm{a}} \mathrm{E}$ denotes an estimate (see text for explanation); actual number counted is in [ ].

'Nest success is the percent of nests hatching $\geq y g$. Calculated $(C)$ percent determines success from time a nest is located ${ }^{12}$. Green's estimator $(G)$ converts observed success to an estimate of Mayfield's calculated success ${ }^{4}$.

${ }^{\circ} E$ denotes an estimate: assumes all yg counted on a July brood census fledge. Pair sucess is the observed percent of prs fledging $21 \mathrm{yg}$.

W.C. Harris, Unpubl. data. Counted 0 birds on a 28 June census; little beach area due to high water.

D. Hjestaas, Unpubl. data. A 30 May-1 June census of most of the habitat ( 3 sections not censused). A 6-7 July brood census ( 34 adults). Fledging success: assumes the $27 \mathrm{yg}$ were from 39 nests. Pair success: assumes the 15 prs with $\geq \mathrm{yg}$ on the brood census all fledged $>1 \mathrm{yg}$.

'Data from 3 study siotes, each approx. $1.5 \mathrm{~km}$ : near Qu'Appelle and Gardiner Dams, and w of Sage Bay. Nest success: 23 of 30 nests hatched $\geq 1 \mathrm{yg} ; 1$ nest was lost to flooding, 6 to unknown predators or human disturbance. Fledging success: 28 nests with known fate fledged $55 \mathrm{yg}$. Assumes yg not fledged by 23 July survuve. Pair success: 20 of 28 nests fledged $>1 \mathrm{yg}$.

Eata from the 1992 study sites ${ }^{1}$ and 2 additional sites, each approx. $1.5 \mathrm{~km}$ : e of Sage Bay and $10 \mathrm{~km} \mathrm{nw}$ of town of Elbow. Nest success: 9 of 39 nests hatched $z \mathrm{yg} ; 23$ nests were lost to flooding, 7 to unknown predators. Pair success: 2 of 39 prs fledged $\geq \mathrm{yg}$.

A 27-31 May census. The 30 prs and 5 territorial singles counted in the Thomsom and McKenzie Arms are assumed to be 35 prs with nests. 
${ }^{7}$ In 1988, 34yg on an early July brood census of the ASrms. Fledging success assumes the 34 yg were from 35 nests. In 1989, a 6-8 June census of most of the Arms; Riverhurst Ferry to the Arms not censused. Fledging success: 8 and 11 July brood census (56 adults, 13 family groups). Assumes the $27 \mathrm{yg}$ were from 35 nests.

${ }^{8} \mathrm{~A} 14$ June census of the Arms; Riverhurst Ferry to the Arms not censused. No birds on a 4 July brood census.

${ }^{9}$ Counted 91 nests (223 adults) in the Arms on a 1, 2 and 8 June census. Fledging success: 6-7 July brood census of the Arms (20 adults, 6 family groups). Assumes the $7 y g$ were from 91 nests.

${ }^{10} \mathrm{~A}$ 9-10 July census of shoreline totalling $243 \mathrm{~km}$; several sections of habitat not sensused.

${ }^{11}$ One nest not found but pr was subsequently located with 2 yg (4 eggs, all hatching, are assumed). Pair success: 5 of 20 prs fledged $\geq 1 \mathrm{yg}$.

${ }^{13}$ Counted 96 adults (45 prs) on an early June sensus of selected beaches; 6 more without nest counted by T. Tyndall in 2 additional areas. Pair success: 1 yg survived $>1$ wk, likely did not fledge due to high water and greatly reduced habitat.

${ }^{14}$ Monitored 22 nests at 3 sites: 8 near Qu'Appelle Dam, 7 near Gardiner Dam, and 7 near Sage Bay. Nest success: may be an overestimate as (unlocated) neast may have flooded before moniitoring began on 9 June. Of 22 nests, 13 hatched $z y g ; 9$ were lost to flooding.

${ }^{20} \mathrm{~A}$ 2-15 June census. Number of pairs: 54 pairs and 24 territorial singles. Nest success: 27 of 40 nests hatched $\geq 1$ yg. Fledging success: $8-13$ July brood census (104 adults; 50 prs); estimate that 62 nested in the area censused. Assumes the 92 yg were from 62 prs and that all yg not fledged by 23 July survive.

Table 2. Nest Chronology for Piping Plovers at Lake Diefenbaker, Saskatchewan

\begin{tabular}{||c|c|c|c|c|}
\hline Year & $\begin{array}{l}\text { Number } \\
\text { of } \\
\text { nests }\end{array}$ & $\begin{array}{l}\text { Mean nest } \\
\text { initiation date } \\
\text { (range) }\end{array}$ & $\begin{array}{l}\text { Mean hatch } \\
\text { date } \\
\text { (range) }\end{array}$ & $\begin{array}{l}\text { Mean fledge } \\
\text { date } \\
\text { (range) }\end{array}$ \\
\hline $1991^{14}$ & 13 & $\begin{array}{c}\text { May 14 } \\
\text { (May 11-28) }\end{array}$ & $\begin{array}{c}\text { June 17 } \\
\text { (Jun 14-Jul 1) }\end{array}$ & $\begin{array}{c}\text { July 14 } \\
\text { (July 11-28) }\end{array}$ \\
\hline $1992^{1}$ & 22 & $\begin{array}{c}\text { May 11 } \\
\text { (May 5-June 1) }\end{array}$ & $\begin{array}{c}\text { June 14 } \\
\text { (Jun 8-Jul 5) }\end{array}$ & $\begin{array}{c}\text { July 11 } \\
\text { (July 5-32) }\end{array}$ \\
\hline $1993^{2}$ & 9 & $\begin{array}{c}\text { May 7 } \\
\text { (May 3-13) }\end{array}$ & $\begin{array}{c}\text { June 10 } \\
\text { (June 6-16) }\end{array}$ & $\begin{array}{c}\text { July 7 } \\
\text { (July 3-13) }\end{array}$ \\
\hline $1995^{13}$ & 6 & $\begin{array}{c}\text { May 8 } \\
\text { (May 6-13) }\end{array}$ & $\begin{array}{c}\text { June 11 } \\
\text { (June 9-16) }\end{array}$ & $\begin{array}{c}\text { July 8 } \\
\text { (July 6-13) }\end{array}$ \\
\hline $1996^{11}$ & 5 & $\begin{array}{c}\text { May 19 } \\
\text { (May 14-28) 22 }\end{array}$ & $\begin{array}{c}\text { July 19 } \\
\text { (Jun 17-Jul 1) 14-28) }\end{array}$ \\
\hline Average & & May 11 & June 14 & July 11 \\
\hline
\end{tabular}

anitiation date is calculated using six days average laying time plus 28 days for incubation period. ${ }^{5}$

${ }^{8}$ Fledge date is calculated as 27 days after hatch date. ${ }^{5}$

${ }^{1}$ Excludes 1 probable renest (hatched 12 July).

${ }^{11 E x c l u d e s} 2$ probable renests (hatched 16 and 28 July). 